\title{
Antimicrobial Efficacy of Selected Ayurveda Formula against Laboratory Specimen of Staphylococcus aureus
}

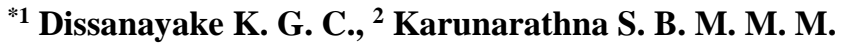 \\ 1. Senior Lecturer Gr. I, Department of Cikitsa, Gampaha Wickramarachchi Ayurveda Institute, University of Kelaniya, \\ Yakkala, Sri Lanka.
}

2. Gampaha Wickramarachchi Ayurveda Institute, University of Kelaniya, Yakkala, Sri Lanka.

DOI: 10.29322/IJSRP.10.03.2020.p9925

http://dx.doi.org/10.29322/IJSRP.10.03.2020.p9925

\begin{abstract}
Selected formula consisted of three ingredients including dried leaves of Azadirachta indica, dried seeds of Sesamum indicum and Bees' honey which is clinically use for open wounds. The current study was designed as a microbiological assay and the key objective was to evaluate the antibacterial efficacy of TNK against laboratory specimen of Staphylococcus aureus (ATCC25923). The Anti-Bacterial Sensitivity Test was conducted according to the Kirby Bauer method using Agar Well Diffusion method by comparing the effect of Amoxicillin as the positive controller and distilled water as the negative controller in triplicates. The testing drug was assessed as D1 and D2 in 1:2 concentration ratios respectively. Results of the study were obtained through the diameter measurement of inhibitory zone and assessed using one - sample T - test. D1 depicted $\mathrm{p}$ value as 0.024 and $\mathrm{T}$ - test was 4.44. D2 depicted $\mathrm{p}$ value as 0.100 and $\mathrm{T}$ - test was 1.89 . Comparing to the positive control drug, the hypothesis was generated as $\mathrm{H}_{0}: \mu<=19 \mathrm{~mm}$ and $\mathrm{H}_{1}: \mu>19 \mathrm{~mm}$. Referring to hypothesis, $\mathrm{H}_{0}$ of D1 was rejected and $\mathrm{H}_{0}$ of D2 was not rejected. The significant level was considered less than 5\%. D2 concentration of TNK was significant against laboratory specimen of Staphylococcus aureus. The study suggests that the TNK is consisted with an extrinsic effective antibacterial application for infected wounds which were caused by Staphylococcus aureus. Further clinical study on human subjects will verify the efficacy of TNK in clinical manifestations.
\end{abstract}

Key Words: Antibacterial Activity, Staphylococcus aureus, TNK, Kirby Bauer method

\section{INTRODUCTION}

Herbs are the key ingredients used in Ayurveda medication. Various parts such as barks, flowers, roots etc. are manually processed in different methods to discover their optimal potential efficacy. Among herbs, Azadirachta indica and Sesamum indicum are two herbs widely used in Ayurveda pharmacological practice. The current study discusses on antibacterial efficacy of Thilanimbadi Kalka (TNK) against laboratory specimen of Staphylococcus aureus. The study focusses on wound healing effect due to Staphylococcul infections.

Ayurveda authentic text 'Susruta Samhita' and Kaiyadewa Nighantu highlights that Azadirachta indica is consisting with Vruna Shodhana (wound cleansing) and Krimighna (destroying worms / antibacterial) properties. [1-2] Another authentic text "Bhava Prakash' mentions that leaves of Azadirachta indica is effective in cleansing maggot infested wounds. [3] Several recent studies have already proven that Azadirachta indica is consisting with antibacterial effects against Staphylococcus aureus. [4-5] 
Effective antibacterial properties are available in Sesamum indicum plant, specially for common skin pathogens such as Staphylococcus and Streptococcus infections. [6] Ancient Ayurveda literature elaborates positive evidences on antimicrobial effect of Sesamum indicum plant including wound cleansing and wound healing effect. [7, 8, 9]

Bees' honey clears wound infection to facilitate healing of deep surgical wounds with infection. [10-11] Antimcrobial effect of bees' honey against Staphylococcus aureus is considerably high. [12]

Azadirachta indica, Sesamum indicum and Bees' honey individually contain antimicrobial properties against wounds infected with Staphylococcus aureus. Thilanimbadi Kalka (TNK) is prepared using Azadirachta indica, Sesamum indicum and Bees' honey. Therefore, the current study was conducted to evaluate the antibacterial activity of Thilanimbadi Kalka (TNK) against laboratory specimen of Staphylococcus aureus.

\section{METHODOLOGY}

\section{Collection of Plant Materials}

Fresh leaves of Azadirachta indica and Seeds of Sesamum indicum were collected at Thambagalle area of Nikadalupotha, Kurunegala District in Sri Lanka. Bees' honey was collected at Galgamuwa of Kurunegala District in Sri Lanka.

\section{Culture and Maintenance of Microorganisms}

Pure cultures of Staphylococcus aureus (ATCC 25923) were obtained from the Medical Technology Division of Gampaha Wickramarachchi Ayurveda Institute, University of Kelaniya, Sri Lanka. The pure bacterial cultures were maintained on nutrient agar medium. Each bacterial was further maintained by sub culturing regularly on the same medium and stored at $4^{\circ} \mathrm{C}$ before use in experiments. Kirbys' Single disc antibiotic sensitivity testing of Staphylococci was used in the current study. [13]

\section{Preparation of Testing Drug Extract}

The testing drug was prepared according to the 'Kalka Paribhasha' of Sharangadhara Samhita, 'Fresh raw materials should be obtained in double quantity. Liquids should be obtained in double quantity. Drug should be grounded well in soft paste with no fibrous particles left in it'. [14] Ingredients were authenticated by Department of Dravyaguna Vijnana, Gampaha Wickramarachchi Ayurveda Institute, University of Kelaniya, Sri Lanka.

Fresh leaves of Azadirachta indica and Seeds of Sesamum indicum were collected from source plant were washed for 2-3 times with tap water and finally with distilled water, followed by ethanol wash and then allowed to dry at $30{ }^{\circ} \mathrm{C}$ and $50{ }^{\circ} \mathrm{C}$ for overnight respectively. Herbal ingredients were grounded well into soft paste while adding Bees' honey till no fibrous particle felt in it.

Sample $\mathrm{D}_{1}$ which finely grounded paste, sample $\mathrm{D}_{2}$ which squeezed extract of paste were tested for Antibacterial Sensitivity Test.

\section{Microbiological screening}

Antimicrobial activities of different extracts were evaluated by the Agar Well Diffusion method [15] modified by Olurinola, 1996 [16] and Minimum Inhibitory Concentration (MIC) [17]

\section{Media Preparation and Its Sterilization}

For agar well diffusion method (Murray et al., 1995 later modified by Olurinola, 1996) antimicrobial susceptibility was tested on solid (Agar) media in petri plates. For bacterial assay nutrient agar (NA) $(38.16 \mathrm{gm} / \mathrm{L})$ was used for developing surface colony 
growth. The minimum inhibitory concentration (MIC) and the minimum bactericidal concentration (MBC) were determined by serial micro dilution assay.

The suspension culture, for bacterial cells growth was done by preparing $2 \%$ Nutrient Broth (w/v) taken for evaluation. All the media prepared was then sterilized by autoclaving the media at $\left(121^{\circ} \mathrm{C}\right)$ for $15 \mathrm{~min}$.

\section{Agar Well Diffusion Method}

Agar well-diffusion method was followed to determine the antimicrobial activity. Nutrient agar (NA) plates were swabbed (sterile cotton swabs) with 18 hour old - broth culture of respective bacteria and fungi. Wells (8mm diameter and about $2 \mathrm{~cm}$ a part) were made in each of these plates using sterile cork borer. About $50 \mu \mathrm{l}$ of different concentrations of study drug solvent extracts were added sterile syringe into the wells and allowed to diffuse at room temperature for $2 \mathrm{hrs}$.

Control experiments comprising inoculums without plant extract were set up. The plates were incubated at $37^{\circ} \mathrm{C}$ for $24 \mathrm{~h}$ for bacterial pathogens. The diameter of the inhibition zone $(\mathrm{mm})$ was measured and the activity index was also calculated. Triplicates were maintained and the experiment was repeated thrice, for each replicates the readings were taken in three different fixed directions and the average values were recorded.

\section{Preparation of Inoculum}

The antibacterial assay was carried out by micro-dilution method in order to determine the antibacterial activity of compounds tested against the pathogenic bacteria. The bacterial suspensions were adjusted with peptone water to a concentration of $1.0 \mathrm{X} 107$ $\mathrm{CFU} / \mathrm{ml}$. The inocula were prepared and stored at $4{ }^{\circ} \mathrm{C}$ until use. Dilutions of the inocula were cultured on solid medium to verify the absence of contamination and to check the validity of the inoculum. All experiments were performed in duplicate and repeated three times. According to the turbidity standard method (0.5 McFarland standard), (-1) Dilution series was selected and put in to the Muller-Hinton agar plates.

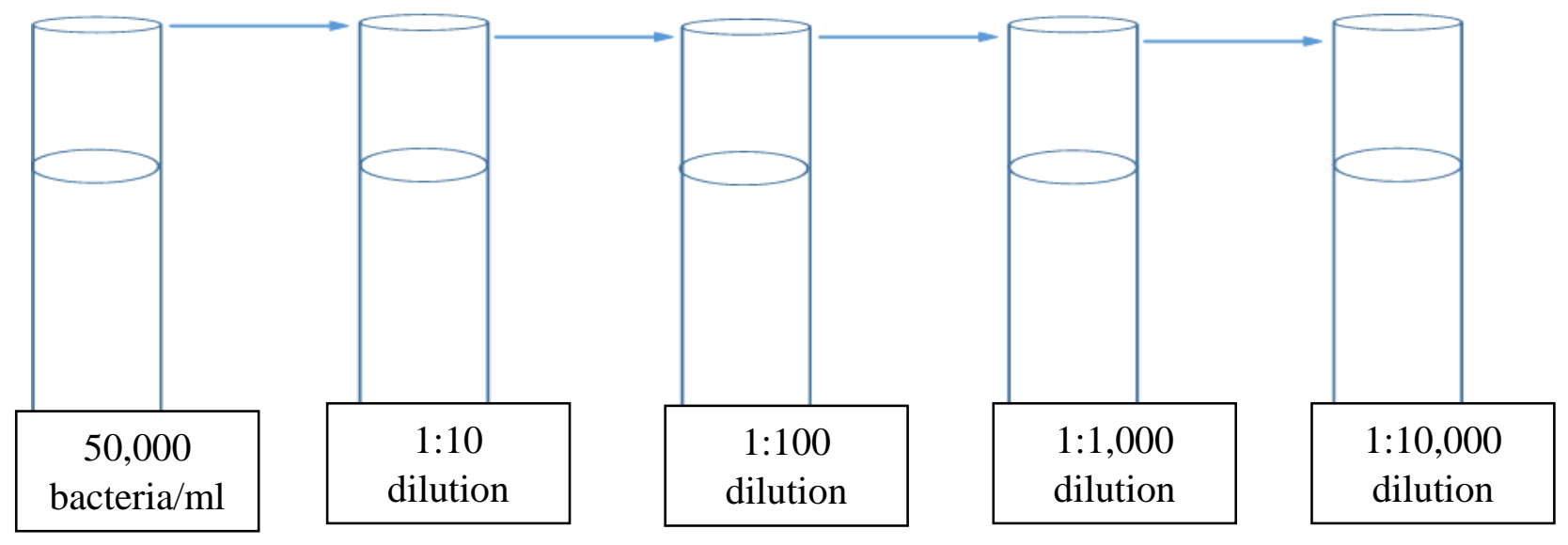

Figure 01: Dilution Series 


\section{Determination of MIC}

The lowest concentrations without visible growth (at the binocular microscope) were defined as MICs. The lowest concentrations without visible growth (at the binocular microscope) were defined as MICs.

\section{Determination of $\mathrm{MBC}$}

The MBCs were determined by serial sub-cultivation of $2 \mu \mathrm{l}$ into plates containing $100 \mu \mathrm{l}$ of broth per well and further incubation for 72 hours.

The lowest concentration with no visible growth was defined as the MBC, indicating $99.5 \%$ killing of the original inoculum and compared with the standards Amoxicillin (Table 01) for Bacteria (Hi-media) as the positive control.

All experiments were performed in duplicates $\left(D_{1} \& D_{2}\right)$ and repeated three times.

Table 01: Standard Amoxicillin Sensitivity Chart

\begin{tabular}{|c|c|c|c|c|}
\hline Antibiotic (Antimicrobial agent) & Disc code & Resistance $(\mu)$ & Intermediate & Susceptible \\
\cline { 3 - 5 } & & $<$ or=mm & mm & $=$ or $>\mathrm{mm}$ \\
\hline Amoxicillin (Other) & AMC & $<13$ & $14-17$ & $>18$ \\
\hline Amoxicillin (Staph) & AMC & 19 & & 20 \\
\hline
\end{tabular}

(Fall. 2011 - Jackie Reynolds, Richland College, BIOL 2421)

Results were compared with the standard Amoxicillin sensitivity chart and drug resistance were taken as $\mu<=19$ vs $\mu>19$.

\section{RESULTS}

Hypothetical assessment elaborates $\mathrm{H}_{0} \mu<=19$ vs $\mu>19$

Table 02: One Sample T Test (Test of $\mu<=19$ vs $\mu>19$ )

\begin{tabular}{|c|c|c|c|c|c|c|c|}
\hline Variable & Sample size & Mean & $\begin{array}{c}\text { Standard } \\
\text { deviation }\end{array}$ & SE Mean & $\begin{array}{c}95 \% \text { lower } \\
\text { bound }\end{array}$ & T value & P value \\
\hline $\mathrm{D}_{1}$ & 3 & 24.33 & 2.08 & 1.2 & 20.82 & 4.44 & 0.024 \\
\hline $\mathrm{D}_{2}$ & 3 & 20.667 & 1.528 & 0.082 & 18.091 & 1.89 & 0.100 \\
\hline
\end{tabular}

Significant level was considered less than or equal $5 \%$. 


\begin{tabular}{|c|c|c|l|}
\hline Sample & T - Test & P - value & Conclusion \\
\hline $\mathrm{D}_{1}$ & 4.44 & 0.024 & $\mathrm{H}_{0}$ is rejected \\
\hline $\mathrm{D}_{2}$ & 1.89 & 0.100 & $\mathrm{H}_{0}$ is not rejected \\
\hline
\end{tabular}

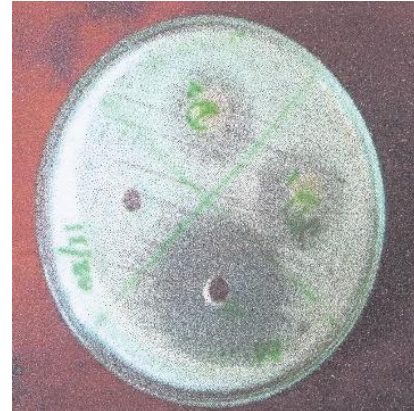

Series 1

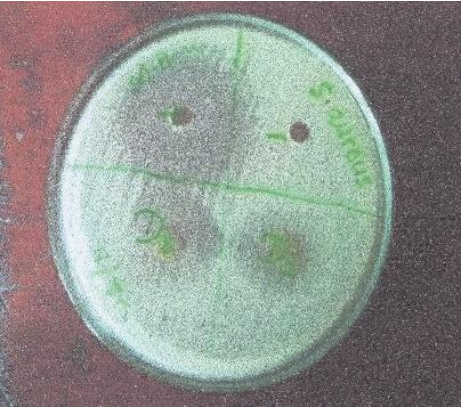

Series 2

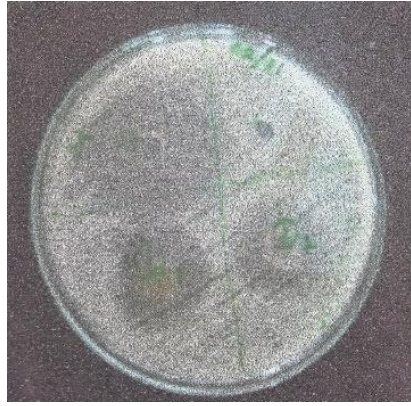

Series 3

Figure 02: Inhibitory Zone Diameters

\section{DISCUSSION}

Considering adverse effects and eco-friendly usage, search for antimicrobials from natural sources has achieved a time-honored attention and efforts have been put in to identify compounds that can act as suitable antimicrobials agent to replace antibiotics carrying adverse effects. [18, 19] Plants derived phytochemicals serve as a prototype to develop more effective medicines in controlling microbial infections. Among Ayurveda medicines, TNK is introduced as a wound disinfectant medicine in Ayurveda authentic text Susruta Samhita.

The current study was subjected to incipient screening for antibacterial activity against laboratory specimen of Staphylococcus aureus. The ABST elaborated mean inhibitory zone diameter of $\mathrm{D}_{1}=24 \mathrm{~mm}$ and $\mathrm{D}_{2}=21 \mathrm{~mm}$. among both samples, finely grounded sample depicted most antibacterial sensitivity.

\section{v. CONCLUSION}

The present investigation elaborates that TNK contains potential antimicrobial components that may be of great use for the development of pharmaceutical industries as a therapy against infected wounds with the purpose of wound cleansing.

\section{REFERENCE}

1. Murthy, K. R. S. (1994). Susruta Samhita - text English Translation, Volume I, $4^{\text {th }}$ ed, Varanasi: Chaukambha Orientalia. p. 50-51.

2. Sharma, P. \& Sharma G. U. (1979), Kaiyadewa Nighantu, $1^{\text {st }}$ ed. Varanasi: Chaukambha Orientalia. p. 163.

3. Murthy, K. R. S. (1998). Bhavaprakasha of Bhavamisra, Volume II (Including Nighantu Portion), $1^{\text {st }}$ ed, Varanasi: Chaukambha Orientalia. p. 188.

4. Francin, U., Jeannette, U. \& Pierre, R. J. Assessment of Antibacterial activity of Neem Plant (Azadirachta indica) on Staphylococcus aureus and Escherichia coli. Journal of Medicinal Plant Studies, 2015; 3(4): 85-91. 
5. Anwar, J., Zahoor, M. A., Zahoor, M. K., Siddique, A. B., Nawaz, Z., Rasool, M. H., Qamar, M. U., Waseem, M., Hussain, S. Z., \& Yasmin, A. Efficacy of Azadirachta indica organic extracts against clinical methicillin resistant Staphylococcus aureus isolates. Pakistan Journal of Pharmacological Science. 2018; Jul; 31(4(Supplementary)): 1485-1488.

6. Shah, N. C. (2013). Sesamum indicum seeds and oil, a Historical and Scientific Evaluation from Indian Perspective. Indian Journal of History of Science, 48(2): 151-174.

7. Sharma, P. \& Sharma, G. U. (1979), Kaiyadewa Nighantu, $1^{\text {st }}$ ed. Varanasi: Chaukambha Orientalia. p. 121.

8. Tripathi, I. (1982). Raja Nighantu, $1^{\text {st }}$ ed. Varanasi: Chaukambha Orientalia.

9. Shastri, S. (1931). Chakradatta by Chakrapanidatta. $2^{\text {nd }}$ ed. Lahore: Mehar Chand Lanchmandas.

10. Lee, D., Sinno, S. \& Khachemoune, A. (2011). Honey and Wound Healing. American Journal of Clinical Dermatology. 12. 181-90.

11. Yaghoobi, R., Kazerouni, A., \& Kazerouni, O. (2013). Evidence for Clinical Use of Honey in Wound Healing as an Anti-bacterial, Anti-inflammatory Anti-oxidant and Anti-viral Agent: A Review. Jundishapur journal of natural pharmaceutical products, 8(3), 100104.

12. Almasaudi, Saad \& Al-Nahari, Alaa \& El-Ghany, El \& Barbour, Elie \& Muhayawi, Saad \& AL Jaouni, Soad \& Azhar, Esam \& Qari, Mohammed \& Qari, Yousif \& Harakeh, Steve. (2016). Antimicrobial Effect of Different Types of Honey on Staphylococcus aureus. Saudi Journal of Biological Sciences. 24(6).

13. Bauer, A. W., D. M. Perry, and W. M. M. Kirby. (1959). Single disc antibiotic sensitivity testing of Staphylococci. A.M.A. Arch. Intern. 104:208-216.

14. Nagodavithana, p. (2001). Sri Sharangadhara Samhita, $1^{\text {st }}$ ed. Maradana: Samayawardhana Book Shop Pvt Ltd. p. 10 \& 123.

15. Murray, P. R., Baron, E. J., Pfaller, M. A., Tenover, F. C. \& Yolken, H. R. (1995) Manual of Clinical Microbiology, 6th Ed. ASM Press, Washington DC. p. 15-18.

16. Olurinola, P. F. (1996). A laboratory manual of pharmaceutical microbiology, Idu, Abuja, Nigeria. p. 69-105.

17. Akinyemi, K. O., Oladapo, O., Okwara, C. E., Ibe, C. C. \& Fasure, K. A. (2005). Screening of Crude Extracts of Six Medicinal Plants Used in South - West Nigerian Unorthodox Medicine for Antimethicillin resistant S. aureus activity. BMC Comp. Alt. Med; 5(6): p. 17.

18. Kelmanson JE, Jager AK and Vaan Staden J. (2000). Zulu medicinal plants with antibacterial activity. J. Ethanopharmacol. 69: 241246.

19. Ahmad I and Beg AZ. (2001). Antimicrobial and phytochemical studies on 45 Indian medicinal plants against multiple drug resistant human pathogens. J. Ethanopharma. 74: 113-123.

\section{First Author: K. G. C. Dissanayake}

Senior Lecturer, Department of Cikitsa, Gampaha Wickramarachchi Ayurveda Institute, University of Kelaniya, Yakkala, Sri Lanka.

Email: chithramalad@kln.ac.lk

\section{Second Author: S. B. M. M. M. Karunarathna}

Gampaha Wickramarachchi Ayurveda Institute, University of Kelaniya, Yakkala, Sri Lanka.

\section{Corresponding Author: K. G. C. Dissanayake}

Senior Lecturer, Department of Cikitsa, Gampaha Wickramarachchi Ayurveda Institute, University of Kelaniya, Yakkala, Sri Lanka.

Email: chithramalad@kln.ac.lk 
ISSN 2250-3153 